\title{
GEOHISTORICAL PHASES OF PLANNING STRUCTURE DEVELOPMENT IN THE CITY OF IVANO-FRANKIVSK
}

\author{
Olha LEVYTSKA \\ Taras Shevchenko National University of Kyiv, Ukraine \\ charmyolichka@gmail.com
}

\begin{abstract}
For a better understanding how to make a city planning of any city in the future, you should always carry a digression into history. The current study examines the concept of "geohistory of the city", exploring the peculiarities of Ivano-Frankivsk planning structure formation at the different transformation stages, so called geohistorical phases, since the city's founding to the present. Also, the paper describes historical transformation of the functional zoning of Ivano-Frankivsk, i.e. description of the main urban functions at each of the previously mentioned stages.
\end{abstract}

Key words: geohistorical phases, city planning, Ivano-Frankivsk.

DOI: http://dx.doi.org/10.17721/2413-7154/2016.75.74-79

UDC: 911.3

\section{ГЕОІСТОРИЧНІ ЗРІЗИ РОЗВИТКУ ПЛАНУВАЛЬНОЇ СТРУКТУРИ МІСТА ІВАНО-ФРАНКІВСЬКА}

\author{
ОЛЬГа ЛЕВИЦЬКА \\ Київський начіональний університет імені Тараса Шевченка, Україна \\ charmyolichka@gmail.com
}

\begin{abstract}
Анотація: Для кращого розуміння того, як правильно побудувати схему планування будь-якого міста в подальшому, завжди потрібно здійснювати екскурс в його історію. У представленому дослідженні розглянуто поняття «геоісторії міста», розкриваються особливості формування планувальної структури міста, на прикладі Івано-Франківська, виділено та охарактеризовано основні етапи трансформації планувальної структури міста, так звані геоісторичні зрізи, від моменту заснування міста до сучасності, та визначено історичні трансформації функціонального зонування міста Івано-Франківська, тобто опис основних міських функцій на кожному з виділених етапів.
\end{abstract}

Ключові слова: геоісторичні зрізи, міське планування, Івано-Франківськ.

DOI: http://dx.doi.org/10.17721/2413-7154/2016.75.74-79

УдК: 911.3

Вступ. Регіоналізація України є об'єктивним еволюційним історично зумовленим процесом, результатом взаємодії таких чинників, як політичних адміністративно-територіальних перетворень, різноманітності природного ландшафту, етнічних територіальних відмінностей, закономірностей розвитку мережі міських поселень та формування їхніх територіальних систем. Сьогодні більшість міст України перебувають в стані трансформації своїх планувальних структур. Дослідження історичних змін таких трансформації дає можливість глибше пізнати закони, за якими місто розвивалося.

Геоісторія міста - це історична перспектива взаємозв'язку планувальної структури і просторового порядку (розпланування міста, його «урбаністичної форми») 3 соціальним порядком. Тобто то йдеться про те, як місто планувалось $\mathrm{i}$ виглядало у певні періоди історії, і як це впливало на мешканців, їхні уявлення і спосіб життя тощо. Етапи становлення міста дозволяють нам чіткіше побачити минуле, проаналізувати чинники його становлення.

(с) О. Левицька
Вивчення та аналіз змін таких чинників впродовж історичного розвитку - це важливе завдання, яке дозволяе зрозуміти “генетику" кожного міста i якимось чином спланувати його розвиток в подальшому.

Аналіз попередніх досліджень. Дослідженнями в даній галузі займалися ціла плеяда вчених як архітекторів, так і економістів та географів. Зокрема значний внесок в розвиток таких досліджень зробили Г. Мюнтер, Е. Еглі, Б. Зеві та ін., у тому числі російські автори - В.А. Лавров, А. Е. Гутнов. Дослідженням саме міста Івано-Франківська займались такі вчені як Лукомська 3., Соколовський 3., Шпільчак В., Поліщук Л.

Основна мета даного дослідження: виділення геоісторичних зрізів розвитку планувальної структури міста на прикладі Івано-Франківська.

Виклад основного матеріалу. Протягом 16-18 століть в Європі будувалося мало міст. Урбаністичне розростання міст - концентрувалося загалом у великих існуючих містах і містах, що стали великими у цей час; а ортогональна (прямокутна) планувальна сітка в часи Ренесансу має пріоритетний статус, iï 
застосовують постійно, коли йдеться про розширення вже існуючих міст, бо це - найзручніший та економний спосіб розбудови з «чистого листа». Містаз прямокутною розпланувальною структурою широко розповсюдились в європейському містобудуванні XII - XV ст., i, очевидно, вони наслідували традиції античної містобудівельної думки.

Для новозакладених міст та міст, що розвивалися на західних землях України в XIV - XVII ст. була характерна прямокутна регулярна або так звана “шахова” система планування, тісно пов'язана 3 традиціями західноєвропейського містобудівництва. Поширеністьмістзсхожоюпланувальноюструктурою дозволяє припустити існування конкретних правил і закономірностей, покладених в основу іiі побудови [3]. Одним 3 прикладів таких міст можна назвати і Івано-Франківськ, яке поєднало в собі всі найхарактерніші риси передового середньовічного західноєвропейського містобудівного планування та архітектурних стилів.

Місто Івано-Франківськ (до 1962 року Станиславів) було засноване в 1662 році (рік отримання ним Магдебурзького права) на території села Заболоття, у межиріччі двох Бистриць. Ідея заснування великого, добре захищеного містафортеці, за історичними джерелами, належала Станіславу Ревері Потоцькому, польському магнату, а втілена була його сином Андрієм. Місто розташоване було на рівнинній болотяній місцевості, бастіонні укріплення давали змогу вести ефективний фронтальний i бічний артилерійський обстріл. Територія, на якій постало місто, була малопридатна для рільництва, річки та болота додатково захищали від ворогів, а торгові шляхи, що пролягали через місцевість, забезпечували розвиток Станіславова як важливого економічного центра. Можемо виділити кілька етапів трансформації планувальної структури міста, так званих геоісторичних зрізів:

\section{1 етап (середина-кінець 17 століття)}

Місто мало форму шестикутної бастіонової фортеці, у яку вписано квадратну ринкову площу та систему міських кварталів, що узгоджувались особливостями накладки шестикутного та прямокутного планів (рис.1). У місто провадили три мости до двох брам та однієї Вірменської фіртки, що були розташовані посередині куртин фортеці. Південно-західний в’їзд був додатково захищений равеліном. Серед цього розпланування розташовано також палац власника міста. [4] Що ж стосується функиіональності міста, то на даному етапі розвитку місто виконувало житлову, оборонну, сакральну, палацову, виробничу, адміністративну, торгову та функцію обслуговування населення. Ядром міської забудови стала площа Ринок, на якій виконувались більшість 3 вище перелічених функцій. Центральну частину міста створювали за принципом європейських «ідеальних міст» епохи Відродження. Можна простежити чітку геометрію вулиць, що формували квартали. Вулиці виходили на головну площу або до тих вулиць, що вели до в’їних брам. Перші будівлі в місті були дерев'яні, одно- і двоповерхові.

\section{2 етап (кінець 17 - кінець 18 століття)}

Характерними його ознаками стало будівництво нової резиденції міських власників, а саме поява нового планувального елементу - резиденції Потоцьких, яка доповнює існуючу розпланувальну структуру. Спостерігаємо модернізацію оборонної системи міста. Станіславів набуває форми видовженого восьмикутника 38 бастіонами в зв'язку 3 будівництвом мурованої резиденції Потоцьких. Новий палац виростає на північний-схід від міста, де були виведені нові фортифікаційні споруди. (рис.2) 3'являється система ровів та валів, а також вдосконалення бастіонної оборонної системи. В міста з'являються також ряд нових функцій, а саме додається освітня функція. В 18 ст. з'являється у місті вища школа та створюються братства при релігійних осередках. Також спостерігаємо трансформацію функцій попереднього етапу, а саме з будівництвом у місті великого палацового комплексу, сюди переміщується і адміністративна функція. Станіславів стає важливим торговим центром. За переписом, у 1720 році в місті налічується близько 27 крамниць. Будинки, які утворювали периметричну забудову навколо ратуші, називались «прибутковими». Будівлі були переважно дво- і триповерхові. [4]

3 етап (початок 19 - початок 20 ст.)

Що стосується даного етапу, то можемо спостерігати перерозподіл у міському функціональному зонуванні. Було ліквідовано оборонну систему в місті, а саме засипано рови i знищено фортифікаційні споруди. Колишні передмістя зливаються 3 середмістям, а отже спостерігаємо також розповзання міських функцій на територію передмістя. Функціональна структура, можна сказати, втрачає свій центричний характер, головні міські функції розташовуються по всій території міста. В 18-19 століттях зникає також палацова функція, а на території резиденції засновників міста з'являється військовий госпіталь. Новим головним громадським центром стає новоутворена центральна площа (сучасна площа біля Драматичного театру ім. Івана Франка), яка також перебирає на себе рекреаційні та відпочинкові функції.

\section{4 етап (20 століття)}

У радянський період місто активно розвивалось, освоюючи новий простір. Його розбудовували планово, комплексно і під жорстким державним контролем. Основними рисами даного етапу можна назвати втрату великої кількості автентичної житлової забудови, утворення центральних площ та алей за межами колишнього середмістя, територіальний ріст центру. Доповнення просторової структури середмістя новою житловою та громадською забудовою на місці втраченої [3].

Стало існувати наче два різних міста: старе, 3 вузькими вуличками, різноманітною забудовою, багато декорованими фасадами, i нові одноманітні квартали. 3 сірою панельною забудовою і нагромадженням промислової території 3 непривабливими бетонними огорожами. Також можна виділити мережу підцентрів міста, які 


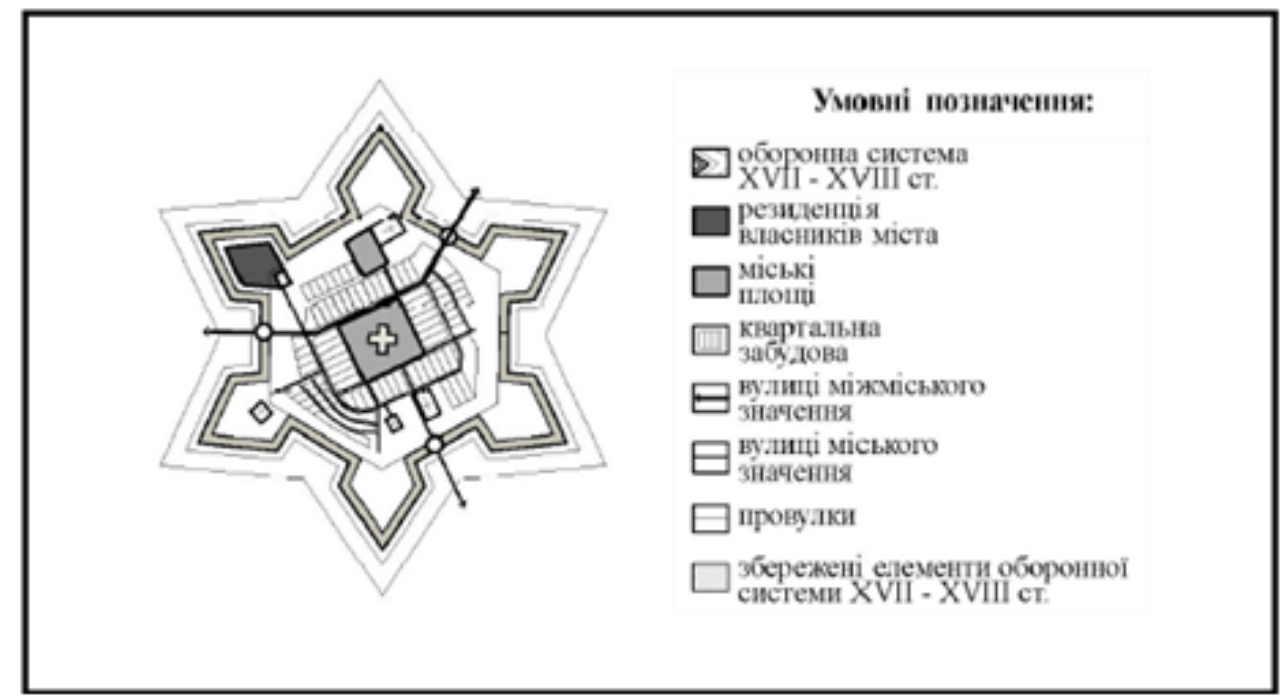

Рис. 1. Розпланувальна структура міста середини 17 ст.

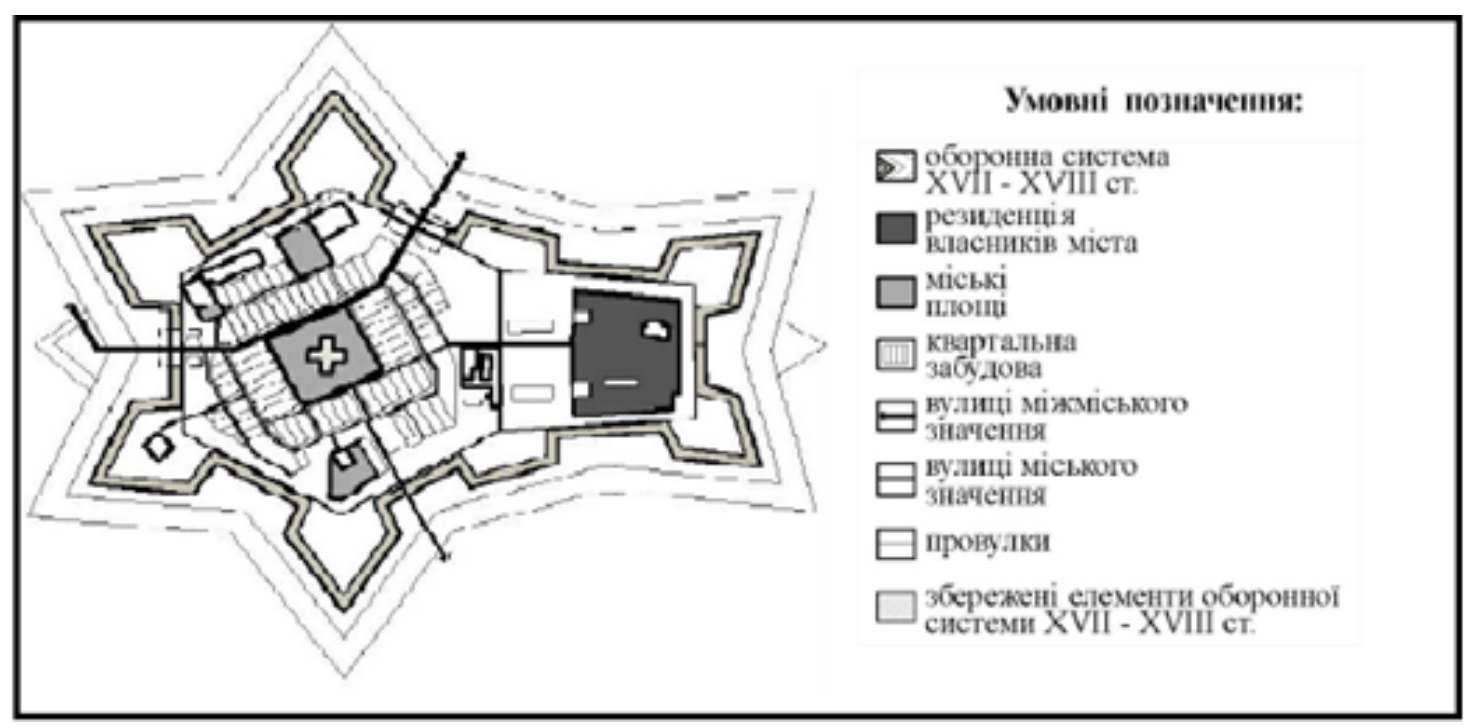

Рис. 2. Розпланувальна структура історичного ядра міста у 18 ст

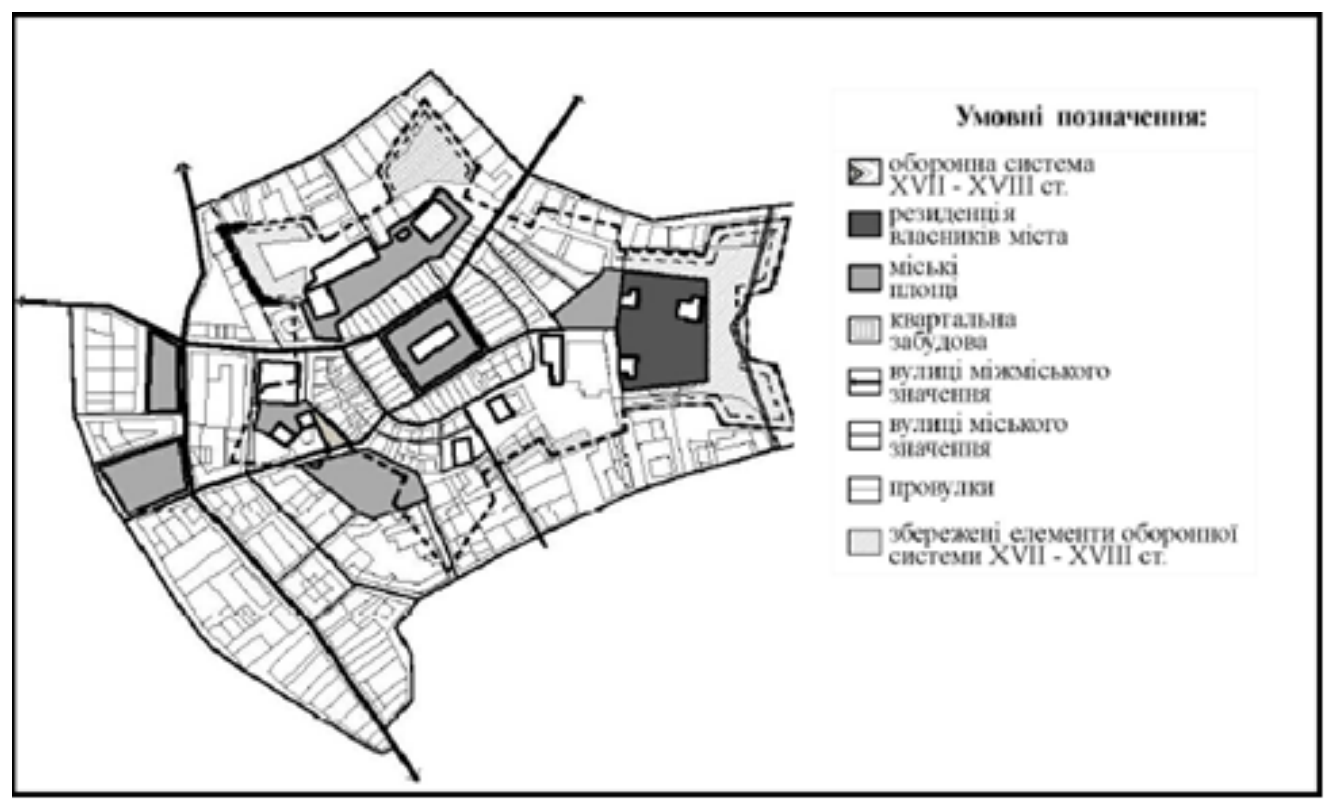

Рис. 3. Розпланувальна структура історичного ядра міста у 19 ст. 
утворюють центральну частину міста. У порівнянні 3 попереднім етапом розвитку площа центру збільшилась за рахунок утворення ансамблю центральної площі 3 музично-драматичним театром. На жаль, відчутними є значні втрати забудови кварталів, які оточують ринкову площу та інших споруд.
У простір історичного середмістя дуже агресивно втрутилась громіздка будівля Облвиконкому, споруджена у 1980-х pp. Ïї величезний об’єм потребував відповідної площі перед головним входом, а масштаб та трираменна форма плану цілком спотворили історичні принципи формування середовища у цій частині міста.

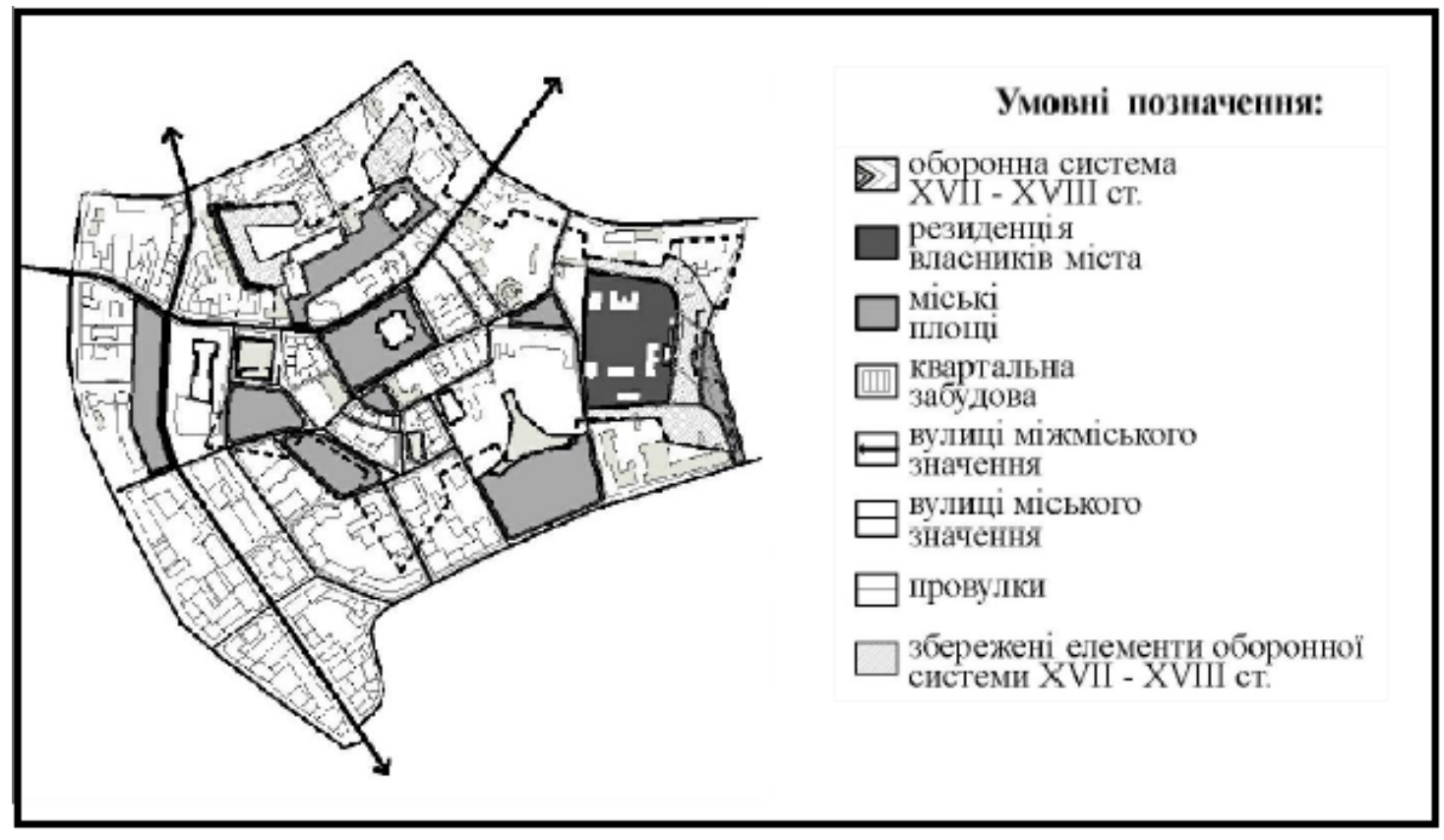

Рис. 4. Розпланувальна структура історичного ядра міста у 20 ст.

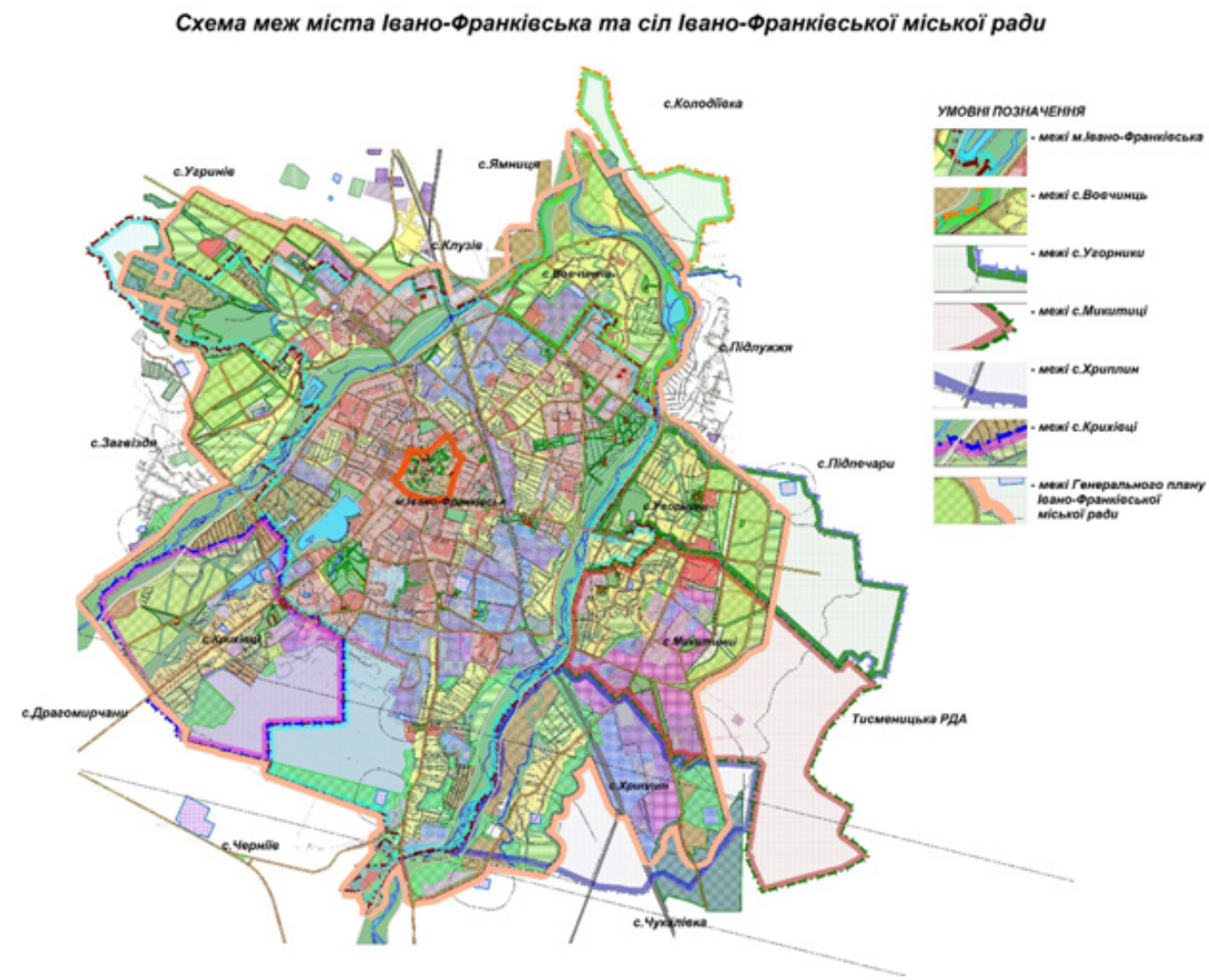

Рис. 5. Сучасні межі міста Івано-Франківська 


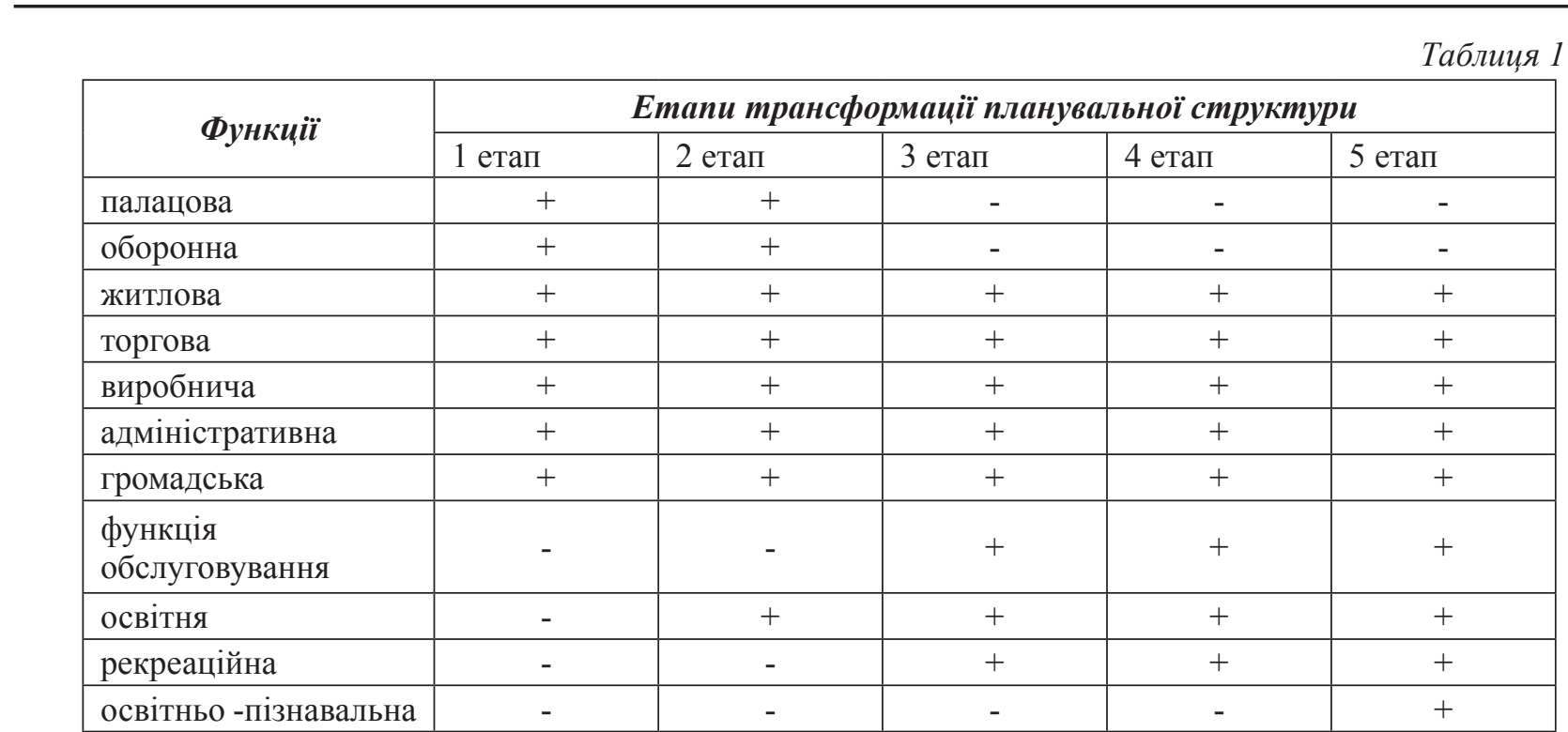

У другій половині 20 століття місто поглинуло навколишні села Софіївку, Вовчинці, Угорники, Рінь, Микитинці, Опришівці, Крихівці, Пасічну. 1978 року затверджено генеральний план ІваноФранківська. який передбачав розбудову нових мікрорайонів, широких автомобільних магістралей. Гепланом передбачено збереження центральної, історичної забудови міста, завершення радіальної системи міських доріг, створення відпочинкових зон, перспективи розвитку міста. [4]

5 етап (кінець 20- початок 21 століття)

Сучасна структура міста значною мірою зберегла особливості первісного розпланування. Передовсім це помітні рештки бастіонних укріплень у західній та північній частинах міста, що переважно збереглись у формі земляних валів. Система вулиць, що сформувалась у наш час повторює зовнішній контур оборонних рубежів лише 3 чотирьох сторін. Це вулиці Новгородська та Дністерська у західній та північній частині історичного центру, Грушевського - в східній. Місце колишнього бастіону зайняв сквер на площі Міцкевича

Центром середмістя й надалі залишається квадратна ринкова площа 3 ратушею у центрі. Можна виділити головні складові центру міста: громадський центр, адміністративний, торгівельний, культурний, відпочинково-рекреаційний. В процесі розвитку центру міста відбуваються переміщення та трансформації даних складових.

Територіально площа центральної частини не змінилась у порівнянні 3 попереднім етапом розвитку, але суттєво змінилось призначення окремих планувальних елементів. Відбулись зміни у громадському житті міста, що відобразилось у призначенні міських просторів, площ, скверів [1].

Сучасне міське планування та забудова міста має цілий ряд недоліків, основними 3 яких $є$ відсутність чіткого функціонального зонування території міста, організації дорожньо-вуличної мережі, а також організації системи обслуговування населення.

Отже, узагальнюючи історичні трансформації функціонального зонування міста Івано-Франків- ська, можемо виділити таку зміну функцій на кожному з вище описаних етапів (табл.1).

Висновки. Отже, міста і системи розселення формуються і розвиваються упродовж тривалого часу. Міські поселення зростають територіально, видозмінюються, зазнаючи оновлень у забудові, у них прокладаються нові комунікації, змінюються функції міста тощо. Було виділено 5 етапів трансформації планувальної структури міста ІваноФранківська: на 1 етапі спостерігаємо заснування міста-фортеці, добре укріпленої, яке мало форму багатокутника, вписаного в коло 3 площею Ринок у центрі, що відповідало тогочасним ідеям містобудування доби Ренесансу. На 2 етапі до існуючого міста фортеці спостерігаємо добудову замку, що змінює форму міста 3 правильної шестикутної, у видовжену з замком, Станиславів стає містом-резиденцією. 3 етап відзначився втратою палацової і оборонної функцій міста, громадський центр поступово переноситься на площу перед сучасним Драматичним театром, також спостерігаємо злиття центральної частини з передмістями та реконструкція житлової забудови. Що ж стосується 4-го, так званого радянського етапу, то спостерігаємо утворення нових мікрорайонів в місті, входження навколишніх сіл в зону обслуговування міста, розбудова промислових територій тощо. Сьогодні, так званий 5 етап характеризується частковим збереженням обрисів того первісного середньовічного міста, але значно видозміненим за рахунок розширення міської території, розбудови вулично-дорожньої мережі в місті, перенесенням громадського центру на Вічевий майдан, а також доповненням функціональності міста функціями, які відповідаю викликам сьогодення.

Таке дослідження дозволяє нам прослідкувати розвиток розпланувальної структури міста, адже такий аналіз у часі дає можливість виявити динаміку функціонування містобудівних об'єктів, зміни під час формування та розвитку поселення, історичну еволюцію архітектурно-просторового середовища, а також врахувати дані міські трансформації при подальшому плануванні міста. 


\section{References:}

1. Lukoms'ka Z. Mìsto Ìvano-Frankìvs'k - İstoriâ ì sučasnìst' [The city of Ivano-Frankivsk - History and modernity]. Visnik NU "L'vivs'ka politehnika". Arhitektura [Bulletin of National University "Lviv Polytechnic". Series: Architecture], 2004, N. 505, pp. 197-201. (In Ukrainian).

2. Poliŝuk L. K. Secesîa v arhitekturì Stanislavova kincâ XIX-počatku XXst. [Secession in the architecture of Stanislav at the end of the XIX - early XX century]. Abstract from PhD Thesis. Kyiv, 2003, 20 p. (In Ukrainian).

3. Tregubova T.A. Planirovka srednevekovogo L'vova (opyt istoriko-gradostroitel'nogo analiza) [Layout of the medieval city (historical and urban planning analysis)]. Abstract from PhD Thesis. Kyiv, 1973, 23 p. (In Russian).

4. Špill'čak V., Sokolovs'kij Z., Golovatij M. Stanislaviv-İvano-Frankivs'k: misto davnê ì sučasne [Stanislav and Ivano-Frankivsk: a city of ancient and modern]. Lviv, 2011, 295 p. (In Ukrainian). 